Jurnal Ilmu Sosial dan Pendidikan (JISIP)

Vol. 6, No. 1 Januari 2022

e-ISSN : 2656-6753, p-ISSN: 2598-9944

DOI: 10.36312/ jisip.v6i1.2697/http://ejournal.mandalanursa.org/index.php/JISIP/index

\title{
Dampak Pemberian Reward and Punishment Untuk Meningkatkan Kedisiplinan Anak Usia Dini
}

\author{
Ririen Arinalhaq ${ }^{1}$, Delfi Eliza ${ }^{2}$ \\ ${ }^{1}$ Mahasiswa Magister Pendidikan Anak Usia Dini Universitas Negeri Padang \\ ${ }^{2}$ Dosen Magister Pendidikan Anak Usia Dini Universitas Negeri Padang
}

\begin{tabular}{l}
\hline Article Info \\
\hline Article history: \\
Received: 08 Desember 2021 \\
Publish: 02 Januari 2022
\end{tabular}

Publish: 02 Januari 2022

\section{Keywords:}

Early Childhood

Reward

Punishment

Discipline

\section{Info Artikel}

Article history:

Diterima 08 Desember 2021

Publis 02 Januari 2022

\begin{abstract}
Discipline is a concept that must be instilled from an early age. How to teach discipline to children at the age of 3-6 years is usually taught in simple things such as tidying up toys, accepting consequences for doing wrong or right, obeying the guidance of parents around, and others. Education aims to train children so that children can be responsible and can realize if there are mistakes they have made. Reward and punishment is an effective way to teach discipline to children. This article aims to describe or conceptually describe the application of reward and punishment to early childhood to train discipline. The method used is a literature study or literature study which contains the opinions of various experts regarding a particular problem which is then examined, compared with the research and researchers who draw conclusions. In this article, the author only analyzes two of them. Several findings from previous studies illustrate that offering these rewards and punishments can improve discipline in children in various ways, such as giving stars, giving praise, giving hand flour, and others. The conclusion of this article is that with reward and punishment, children can better control their emotions and obey the rules that have been given by teachers and parents.
\end{abstract}

\begin{abstract}
ABSTRAK
Disiplin adalah salah satu konsep yang harus ditanamkan sejak usia dini. Cara membelajarkan disiplin kepada anak pada usia 3-6 tahun biasanya diajarkan pada hal-hal sederhana seperti merapikan mainan, menerima konsekuensi apabila berbuat salah atau benar, patuh terhadap tuntunan orang tua maupun lingkungan sekitar, dan lainnya. Pendidikan disiplin bertujuan untuk melatih anak agar anak dapat bertanggung jawab dan dapat menyadari apabila ada kesalahan yang telah diperbuatnya. Reward and punishment adalah cara yang efektif untuk membelajarkan disiplin kepada anak. Artikel ini bertujuan untuk menggambarkan atau mendeskripsikan secara konseptual tentang penerapan reward and punishment kepada anak usia dini untuk melatih kedisiplinan. Metode yang digunakan adalah penelitian studi literatur atau studi kepustakaan yang berisikan tentang pendapat-pendapat dari berbagai pakar mengenai suatu masalah tertentu yang kemudian ditelaah, dibandingkan dengan penelitian peneliti serta ditarik kesimpulan nya. Dalam artikel ini penulis hanya menganalisis sebanyak dua buah saja. Beberapa temuan dari penelitian terdahulu menggambarkan bahwa pemberian reward and punishment ini dapat meningkatkan kedisiplinan pada anak dengan cara yang beragam, seperti memberikan bintang, memberikan pujian, memberikan tepung tangan, dan lain-lain. Kesimpulan dari artikel ini yaitu dengan adanya reward and punishment, anak lebih bisa mengontrol emosi dan menjadi lebih taat peraturan yang telah diberikan oleh guru maupun orang tua.
\end{abstract}

This is an open access article under the Lisensi Creative Commons Atribusi-BerbagiSerupa 4.0 Internasional

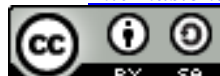

\section{Corresponding Author:}

Ririen Arinalhaq,

Universitas Negeri Padang

Email: ririenadinalhaq@gmail.com

\section{PENDAhULUAN}

Pendidikan adalah sebuah bimbingan yang diberikan secara terstruktur kepada anak agar dapat mengembangkan semua potensi yang ada dalam dirinya dan bertujuan agar anak dapat menjalankan kehidupannya sendiri tanpa bantuan orang lain. Sasaran dari pendidikan itu sendiri adalah manusia, karena manusia memiliki keunikan tersendiri yang tidak dimiliki oleh makhluk lainnya. Media untuk mengembangkan seluruh potensi yang dimiliki oleh manusia itu adalah pendidikan. (Suryana, 2016:4). Pendidikan anak usia dini (PAUD) adalah tempat dimana anak mendapatkan pembinaan secara khusus mulai dari usia lahir sampai usia enam tahun untuk membantu proses tumbuh kembang anak baik jasmani maupun rohani agar anak memiliki kesiapan untuk memasuki 
pendidikan selanjutnya. Dengan adanya pendidikan bagi anak usia dini, kita dapat mengetahui cara membimbing anak dengan baik serta dapat mengetahui potensi-potensi yang ada pada diri anak.

Pendidikan dapat dilakukan dengan cara belajar dan pembelajaran. Belajar dapat dilakukan oleh anak sendiri di sekolah maupun di rumah, sedangkan pembelajaran dilakukan oleh guru dengan anak-anaknya di kelas secara bersama-sama. Di sekolah khususnya di taman kanak-kanak guru berfungsi sebagai motivator agar menumbuhkan semangat anak untuk belajar. Tidak hanya itu, guru sebagai motivator juga harus memberikan suasana pembelajaran yang kondusif serta aktif di dalam kelas dan dengan suasana yang menyenangkan tentunya. Apabila ada anak yang malas belajar maka guru sangat berperan penting untuk menumbuhkan semangat belajar anak tersebut dengan motivasimotivasi yang dapat diserap langsung oleh anak. Salah satu cara untuk meningkatkan minat anak dalam proses belajar adalah dengan memberikan reward and punishment. Memberikan reward ataupun punishment tidak selalu berdampak buruk pada anak, dampak positif yang dapat dilihat seperti memberikan pujian, mengangkat jempol, memberikan bintang, tepuk tangan, mengelus kepala anak, dan lainnya. Selain itu memberikan punishment kepada anak tergambar dengan hal-hal yang buruk seperti memarahi anak dan menghukum anak, tetapi tujuan guru ataupun orang tua memberikan punishment itu agar anak menjadi disiplin kedepannya dan tidak mengulangi kesalahan yang telah dilakukannya. Maka dapat dikatakan bahwa pemberian reward and punishment ini dalam pembelajaran harus dilakukan, tetapi memberikan kedua hal itu harus dengan cara atau tindakan yang positif agar proses pembelajaran di sekolah maupun di rumah dapat berjalan dengan baik dan lancar (Febianti, 2018:93-94).

Memberikan konsep disiplin kepada anak memiliki efek yang sangat besar bagi perkembangan anak, karena jika anak dibesarkan di keluarga yang tidak menerapkan konsep disiplin maka anak akan tumbuh dengan perilaku yang salah. Pada dasarnya disiplin sangat berbeda dengan hukuman. Masa usia dini adalah masa yang paling efektif untuk menerapkan konsep disiplin, dimana pembentukan perilaku anak terjadi pada usia 4-6 tahun. Sedangkan hukuman adalah salah satu cara untuk mendisiplinkan anak, karena hukuman tersebut sebagai bentuk konsekuensi yang telah dilakukan anak secara sengaja, dan diharapkan dengan memberikan hukuman tersebut anak akan sadar dan tidak mengulangi kesalahan yang telah diperbuatnya (Aulina, 2013:37). Tujuan dari disiplin menurut Mulyasa (2012) yaitu untuk membantu anak agar dapat mengatasi timbulnya masalah-masalah serta mencegah timbulnya masalah tersebut. Tujuan lainnya adalah untuk menciptakan suasana yang nyaman, aman dan menyenangkan sewaktu proses kegiatan belajar dan bermain. Sehingga dengan adanya disiplin tersebut, anak akan mentaati semua peraturan yang disampaikan oleh guru. Tidak hanya itu, guru juga harus mampu untuk membantu anak mengembangkan pola perilakunya serta melaksanakan aturan yang telah di buat sebagai alat untuk menegakkan disiplin pada anak (Khoerunnisa, 2017:112).

Pada saat sekarang ini tingkat kedisiplinan anak usia dini masih kurang karena stimulasi yang diberikan oleh orang tua dan guru tidak cocok dengan pola perkembangan yang dimiliki oleh anak, seperti membuang sampah sembarangan, tidak mengikuti peraturan bermain, tidak sabar menunggu antrian, tidak membereskan mainan setelah bermain. Peraturan yang sudah di tentukan oleh sekolah masih banyak yang dilanggar oleh anak, sehingga sikap disiplin tidak tercermin dalam diri anak. Pelanggaran-pelanggaran tersebut terjadi karena tidak adanya konsekuensi yang konsisten yang diberikan oleh guru atas tindakan yang telah dilakukan oleh anak. Kebanyakan guru hanya sekedar mengingatkan anak tanpa ada peringatan yang jelas. Oleh karena itu sikap disiplin pada anak tidak terasah dengan baik dan anak menjadi tidak bertanggung jawab atas kesalahan yang telah diperbuatnya.

Maka dari itu artikel ini akan membahas tentang "Seperti apa dampak pemberian reward and punishment untuk meningkatkan kedisiplinan pada anak usia dini?". Oleh sebab itu artikel ini mencoba mamaparkan dampak memberikan reward and punishment untuk meningkatkan disiplin anak yang ditinjau dari pemberian reward and punishment tersebut khususnya untuk anak usia dini. 
Pembahasan terdiri dari tinjauan tentang dampak pemberian reward and punishment kepada anak, sikap disiplin anak usia dini serta hasil dari beberapa penelitian orang terdahulu yang telah diteliti tentang dampak pemberian reward and punishment untuk meningkatkan kedisiplinan pada anak usia dini.

Disiplin adalah suatu konsep yang harus diajarkan sejak usia dini. Perkembangan disiplin akan berkembang sesuai dengan karakteristik perkembangan anak dari usia 0-8 tahun. Cara membelajarkan disiplin kepada anak pada usia 3-6 tahun biasanya diajarkan pada hal-hal sederhana seperti merapikan mainan, menerima konsekuensi apabila berbuat salah atau benar, patuh terhadap tuntunan orang tua maupun lingkungan sekitar, dan lainnya. Disiplin merupakan sikap sesorang yang menunjukkan bahwa ia patuh dan taat terhadap suatu pekerjaan tertentu atau bertanggung jawab dengan apa yang ia perbuat. Manfaat membelajarkan disiplin kepada anak akan membuat tingkah laku anak lebih terkontrol dan terlatih serta dapat mengarahkan diri tanpa adanya pengaruh dari orang lain (Sabartiningsih, 2018:33-36).

Soetarlinah Sukadji (dalam Mulyadi, 2004:36) mengatakan bahwa pendidikan disiplin yaitu suatu bimbingan yang diberikan dan bertujuan untuk menanamkan suatu kebiasaan dan prilakuperilaku tertentu, terutama untuk meningkatkan kualitas moral dan mental pada anak. Pendidikan disiplin dimulai dari lingkungan keluarga yang dapat diartikan sebagai bimbingan orang tua kepada anak-anaknya untuk menampilkan tingkah laku serta tindakan-tindakan yang sesuai dan dapat diterima oleh norma-norma yang berlaku. Pendidikan disiplin bertujuan untuk melatih anak agar anak dapat bertanggung jawab dan dapat menyadari apabila ada kesalahan yang telah diperbuatnya. Dalam mengajarkan disiplin pada anak, orang tua maupun guru mempunyai aturan-aturan yang harus dipatuhi oleh anak. Peraturan yang dibuat bermacam-macam mulai dari bersikap sopan santun dengan orang lain maupun anggota keluarga sendiri hingga mengatur jadwal main dan belajar. Penerapan disiplin ini tidak selalu berjalan dengan mulus, karena sebagian anak tidak menyukai peraturan yang dibuat oleh orang tuanya. Akibat dari itu, anak terpaksa untuk menjalankan sikap disiplin tersebut. Reaksi anak terhadap keterpaksaan menerapkan sikap disiplin ini adalah rasa marah yang ditunjukkan oleh anak. Menerapkan sikap disiplin yang keras memberikan dampak yang sangat besar pada anak, seperti anak menjadi stress, suka marah, sulit mengontrol emosi, serta menjadi pembangkang karena anak merasa terpaksa dan tidak nyaman dengan peraturan yang telah ditetapkan.

Untuk menghindari keterpaksaan tersebut, menurut Baverly LaHaye (dalam Mulyadi, 2004:36-39) adapun ciri disiplin yang baik untuk anak adalah: (1) Disiplin bersifat membangun. Disiplin tidak dibuat untuk membuat anak frustasi, tertekan, terbabani saat menjalankannya, tetapi anak harus merasa aman dan nyaman saat menjalankan disiplin tersebut. Maka dari itu, orang tua perlu menjelaskan alasan penerapan disiplin serta manfaat disiplin tersebut kepada anak; (2) Disiplin harus bersifat konsisten. Kebanyakan orang tua hanya sekali-sekali menerapkan disiplin kepada anak dan menjadi kurang efektif, sehingga anak akan menjadi bingung dengan penerapan disiplin tersebut. Konsisten dalam menerapkan disiplin kepada anak membuat anak dapat meramalkan apa yang akan terjadi jika ia berperilaku baik atau buruk; dan (3) Disiplin sebagai tanda kasih sayang kepada anak. Membelajarkan disiplin kepada anak tidak harus dengan cara yang otoriter, tetapi dengan cara mendidik anak untuk menjadi orang yang bertanggung jawab. Orang tua juga harus meyakinkan anaknya bahwa sikap disiplin yang orang tua berikan merupakan wujud kasih sayang terhadap anak.

Untuk menerapkan sikap disiplin kepada anak agar anak mau menuruti, biasanya orang tua memberikan imbalan kepada anak. Imbalan tersebut berupa pujian ataupun hadiah (reward). Lama kelamaan apabila orang tua selalu menerapkan cara yang seperti itu maka anak akan mengulangi perilaku disiplin tersebut dengan harapan mendapatkan hadiah ataupun pujian dari orang tua. Banyak yang mengira bahwa cara untuk membujuk anak agar disiplin dengan mengandalkan hadiah, seperti memberi kue apabila anak tidak mau makan, memberi ice cream apabila anak nangis, dan 1927 | Dampak Pemberian Reward and Punishment Untuk Meningkatkan KedisiplinanAnak Usia Dini (Ririen Arinalhaq) 
lain-lain. Namun seiring berjalannya waktu pemberian hadiah untuk mendisiplinkan anak ini akhirnya membawa dampak yang tidak baik, seperti anak akan bertingkah laku baik apabila ada hadiah yang akan diberikan. Selain hadiah orang tua juga sering memberikan pujian kepada anak. Arti dari kata pujian yaitu menyatakan sesuatu hak yang positif kepada seseorang, dan pujian juga merupakan suatu ucapan yang membuat orang yang mendengarnya merasa tersanjung karena perilaku ataupun prestasi yang ada pada diri orang tersebut. Contoh memberikan pujian kepada anak adalah "wah hebat", "pintar", "gambar nya bagus sekali", ataupun dengan membelai kepala anak, tos, memberikan jempol, dan lain-lain. Pujian yang diberikan harus dimengerti oleh anak karena terkadang anak usia dini saat diberikan pujian, mereka tidak mengetahui perilaku seperti apa yang sedang ia lakukan (Mini, 2011:21-23).

Sebaliknya, jika anak tidak disiplin maka orang tua memberikan hukuman kepada anak. Tujuan dari pemberian hukuman ini adalah agar anak tidak mengulangi perbuatan tidak baik yang telah dilakukannya. Hukuman (punishment) diberikan ketika anak melakukan kesalahan fatal ataupun munculnya tingkah laku yang buruk. Pada zaman saat sekarang ini, pemberian hukuman kepada anak banyak menggunakan hukuman fisik misalnya mencubit, memukul, menampar, dan lain-lain. Punishment sebenarnya tidak apa diberikan kepada anak, tetapi punishment yang diberikan bersifat mendidik dan anak paham tentang hukuman yang diberikan oleh orang tua atau gurunya. Ketika tingkah laku buruk anak muncul, orang tua ataupun guru harus tetap melaksanakan hukuman dan memberikan pengertian kepada anak kenapa ia sampai dihukum. Hukuman yang diberikan tidak boleh terlalu berat atau terlalu sering, karena sewaktu memberikan hukuman yang berat biasamua kita sebagai orang tua maupun guru dalam kondisi marah dan sulit mengontrol emosi, sebab dari itu maka akan berdampak pada psikis anak. Selain itu apabila hukuman yang diberikan pada anak dengan kekerasan dan kemarahan, maka nantinya anak akan menjadi orang yang bersifat keras dan kasar kepada orang lain (Mini, 2011:24-27). Dalam pendidikan anak usia dini, punishment berperan penting sebab apabila pendidikan yang diberikan terlalu lunak maka akan membentuk anak kurang disiplindan tidak mempunyai pendirian. Prinsip punishment dalam pendidikan diterapkan sebagai motivasi atau dorongan kepada anak agar anak dapat belajar dengan sungguh-sungguh dan mentaati peraturan yang ada. Pemberian hukuman harus dilakukan dengan cara yang tepat dan bijak dan tidak berlebihan. Pemberian hukuman tersebut hendaknya diberikan dengan cara dapat memperbaiki dan mendidik anak ke arah yang lebih baik (Novitasari, 2019:28).

\section{METODE PENELITIAN}

Jenis metode dari artikel ini yaitu studi literatur atau studi kepustakaan. Kegiatan penelitian studi kepustakaan ini adalah dengan cara mengumpulkan informasi serta data dari bermacam-macam sumber yang ada di internet maupun di buku, majalah, koran, jurnal, yang berkaitan dengan masalah yang ingin dipecahkan. Kegiatan studi kepustakaan ini dilakukan dengan cara mengumpulkan, mengolah, serta menyimpulkan data yang telah terkumpul dengan teknik tertentu guna mencari jawaban atas permasalahan yang ada pada artikel ini (Sari, 2020:52). Studi kepustakaan dilakukan dengan tujuan untuk mencari dasar pijakan untuk membangun serta memperoleh landasan teori, kerangka berpikir, dan menentukan suatu hipotesis penelitian. Dengan melakukan studi kepustakaan ini, maka peneliti akan lebih luas mendalami masalah yang sedang diteliti atau yang hendak diteliti (Kartiningrum, 2015:4).

\section{HASIL PENELITIAN DAN PEMBAHASAN}

Pendidikan anak usia dini bertujuan untuk membimbing, melatih, serta mengembangkan kemampuan-kemampuan yang ada pada diri anak. Adanya pendidikan anak usia dini ini dimaksudkan untuk mempersiapkan anak memasuki jenjang pendidikan selanjutnya. Karakteristik dari anak usia dini berbeda-beda, yaitu egosentris, memiliki imajinasi yang tinggi, memiliki rasa keingintahuan yang kuat, bersifat aktif, dan memiliki jiwa petualang. Anak usia dini merupakan 
anak yang baru mengenal dunia, dimana anak perlu dibimbing agar memahami semua yang ada di dunia ini. Salah satu pengenalan yang dapat kita ajarkan kepada anak adalah kedisiplinan. Kedisiplinan merupakan hal yang sangat penting yang harus diajarkan kepada anak karena disiplin membantu anak untuk belajar mengatahui mana yang salah maupun benar dan membuat anak tetap merasa aman. Menanamkan kedisiplinan sejak usia dini dapat membantu anak belajar bertanggung jawab dan memberikan pengaruh terhadap kehidupan bermasyarakatnya kelak.

Cara menanamkan konsep disiplin kepada anak adalah dengan pemberian reward dan punishment. Dengan adanya pemberian tersebut, kita dapat mengetahaui kedisiplinan anak sebelum diterapkannya reward dan punishment dan setelah diterapkan. Menurut penelitian Madiyanah (2020) pemberian reward merupakan suatu penghargaan atau hadiah yang diberikan kepada anak karena telah melakukan suatu hal yang baik maupun benar. Tujuan dari memberikan reward tersebut adalah guna memotivasi anak untuk meningkatkan semangat belajarnya, membina perilaku-perilaku yang baik dan benar, serta membuat anak lebih percaya diri. Dengan pemberian reward kepada anak usia dini memberikan pengaruh yang besar terhadap jiwa anak. Disamping reward mempunyai keunggulan, reward juga memiliki kelahaman yaitu dapat mengakibatkan anak sombong dan meminta lebih hadiah yang diberikan. Maka dari itu pemberian reward kepada anak hanya semestinya saja atau tidak berlebihan. Berdasarkan penelitian yang dilakukan Madaniyah (2020) penerapan reward sangat terpengaruh kepada kedisiplinan anak, dimana anak mulai mampu berbaris dengan rapi, tidak datang terlambat ke sekolah, tertib memasuki kelas, serta memakai atribut atau seragam dengan rapi ke sekolah. Cara peneliti memberikan reward ini adalah dengan bentuk memberikan bintang kepada anak, sehingga anak dapat termotivasi dan mematuhi aturan yang ada di sekolahnya.

Selain pemberian reward, punishment juga merupakan suatu bentuk pemberian motivasi kepada anak agar anak dapat melakukan kebaikan dan meningkatkan prestasi belajar. Suatu hukuman atau punishment adalah hal yang biasa dilakukan oleh guru maupun orang tua, karena maksud dari hukuman tersebut adalah untuk mencegah timbulnya perilaku tidak baik kepada anak. Hal ini sesuai dengan penelitian Sabartiningsih DKK (2018) bahwa menerapkan punishment kepada anak guru menggunakan strategi atau kondisi serta karakter yang dimiliki oleh anak. Membentuk karakter disiplin pada anak tidaklah mudah. Guru harus memberikan bermacam-macam strategi untuk mendisiplinkan anak usia dini. Contohnya seperti ketika anak mengganggu temannya sampai menangis, kemudian guru memberikan punishment dengan cara meminta anak tersebut untuk meminta maaf, apabila anak tidak mau memberikan maaf maka guru bisa menerapkan hukuman time out atau yang biasa disebut dengan memindahkan anak dati situasi yang tidak membuat perilakunya tak terkendali ke situasi yang lebih tenang. Memberikan punishment untuk kedisiplinan anak dilakukan secara tepat, bijak dan tidak berlebihan serta dengan cara yang dapat memperbaiki sikap anak ke arah yang lebih baik. Dalam penelitian ini peneliti mengatakan bahwa penerapan punishment and reward terbukti mampu melatih anak untuk berdisiplin.

\section{KESIMPULAN}

Menanamkan konsep disiplin kepada anak memang harus dilakukan secara bertahap. Untuk mengajarkan disiplin, orang tua atau guru dapat memulai dengan cara melibatkan anak pada kegiatan-kegiatan yang biasa dilakukan bersama. Cara mengajarkan disiplin juga bisa dengan pemberian reward and punishment. Cara ini adalah cara yang paling ampuh agar kedisiplinan anak dapat terasah dengan baik. Reward and punishment harus diterapkan secara konsisten, sebab apabila tidak adanya konsisten maka aturan-aturan yang telah dibuat tidak akan diterapkan anak dengan baik. Pada hasil dan pembahasan menunjukkan bahwa menerapkan konsep reward and punishment terhadap kedisiplinan anak memberikan dampak yang sangat signifikan. 


\section{DAFTAR PUSTAKA}

Aulina, Choirun Nisak. 2013. Penanaman Disiplin Pada Anak Usia Dini. PEDAGOGIA: Jurnal Pendidikan. Volume 2, Nomor 1 (hlm.37)

Febianti, Yopi Nisa. 2018. Peningkatan Motivasi Belajar dengan Pemberian Reward and Punishment yang Positif. Jurnal Edunomic. Volume 6, Nomor 2 (hlm.93-94)

Kartiningrum, Eka Diah. 2015. Panduan Penyusunan Studi Literatur. Mojokerto: Politeknik Kesehatan Majapahit

Khoerunnisa, Eka Yulia. 2017. Penerapan Reward and Punishment untuk Meningkatkan Kedisiplinan Anak Usia Dini. Jurnal Pelita PAUD. Volume 1, Nomor 2 (hlm.112)

Madiyanah, Ayuk Nur dan Farihah, Himmatul. 2020. Meningkatkan Disiplin Anak Usia Dini Melalui Pemberian Reward. Jurnal Teladan. Volume 5, Nomor 1

Mini, Rose. 2011. Disiplin Pada Anak. Jakarta: Direktorat Pembinaan Pendidikan Anak Usia Dini.

Mulyadi, Seto. 2004. Membantu Anak Balita Mengelola Amarahnya. Jakarta: Penerbit Erlangga

Novitasari, Annisa. 2019. Pemberian Reward and Punishment dalam Membentuk Karakter Disiplin Anak pada Sekolah Madrasah Ibtidaiyah. HALAQA: Islamic Education Journal. Volume 3, Nomor 1 (hlm.28)

Sabartiningsih, Mila; Muzakki, Jajang Aisyul; Durtam. 2018. Implementasi Pemberian Reward dan Punishment dalam Membentuk Karakter Disiplin Anak Usia Dini. AWLADY: Jurnal Pendidikan Anak. Volume 4, Nomor 1 (hlm.33-36)

Sari, Milya dan Asmendri. 2020. Penelitian Kepustakaan (Library Research) dalam Penelitian Pendidikan IPA. Natural Science: Jurnal Penelitian Bidang IPA dan Pendidikan IPA. Volume 6, Nomor 1 (hlm.52)

Suryana, Dadan. 2016. Pendidikan Anak Usia Dini Stimulasi dan Aspek Perkembangan Anak. Jakarta: Kencana 